\title{
The Duck Pond: An Autoethnographic Comic
}

Emily Thiessen ${ }^{1}$ University of Victoria, Victoria, Canada

This short comic documents the author's search for ancestral roots. Her family were among the thousands of people who emigrated from Southern China to Southeast Asia during the late $19^{\text {th }}$ and early $20^{\text {th }}$ centuries. The comic follows a trip from her home in Victoria, Canada to Xiamen, China in search of her grandfather's birthplace. The accompanying text discusses the sketches that became the basis for the comic, and how drawing and comics can be used in anthropological research.

Keywords: graphic anthropology, comics ethnography, autoethnography, Chinese diaspora, Hokkien, Xiamen

1 Author's contact email: Contact: mingsan@shaw.ca 

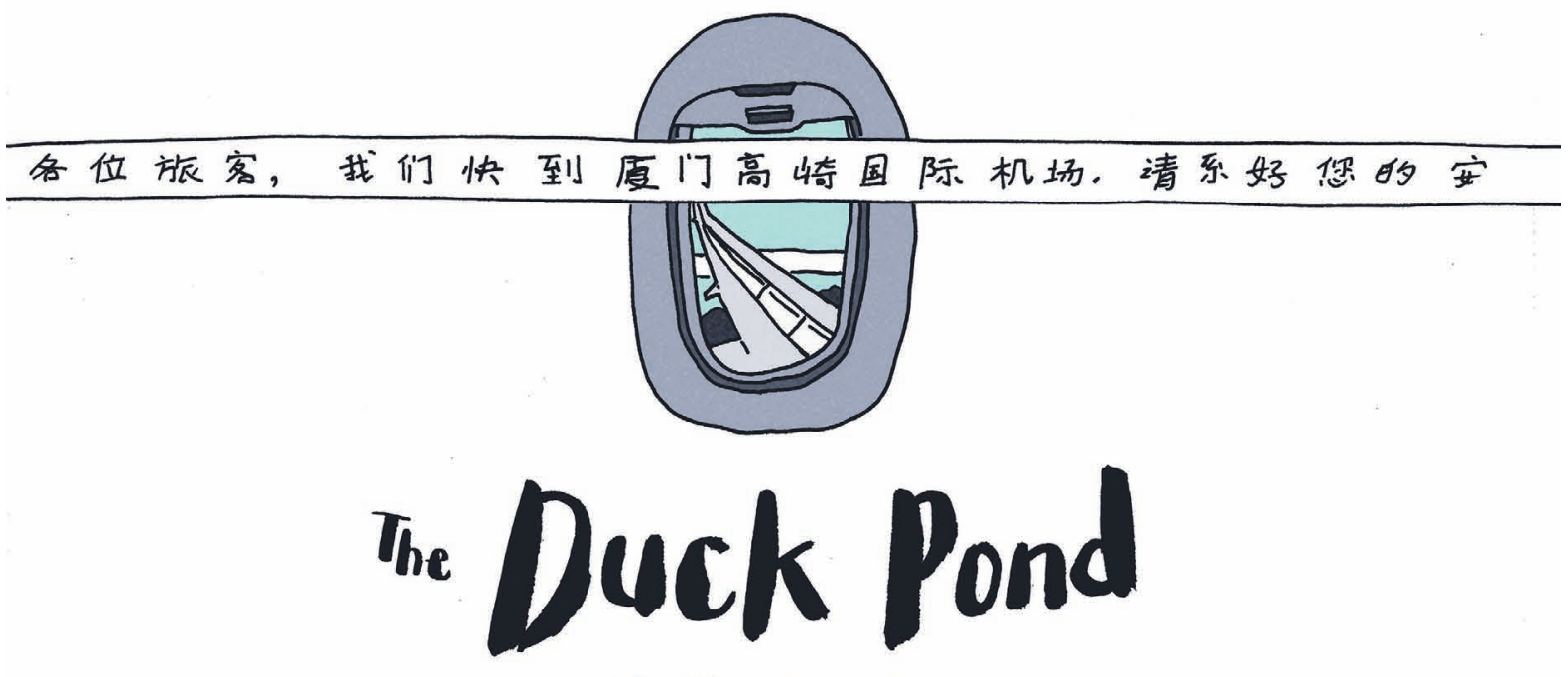

\section{Emily Thiessen}
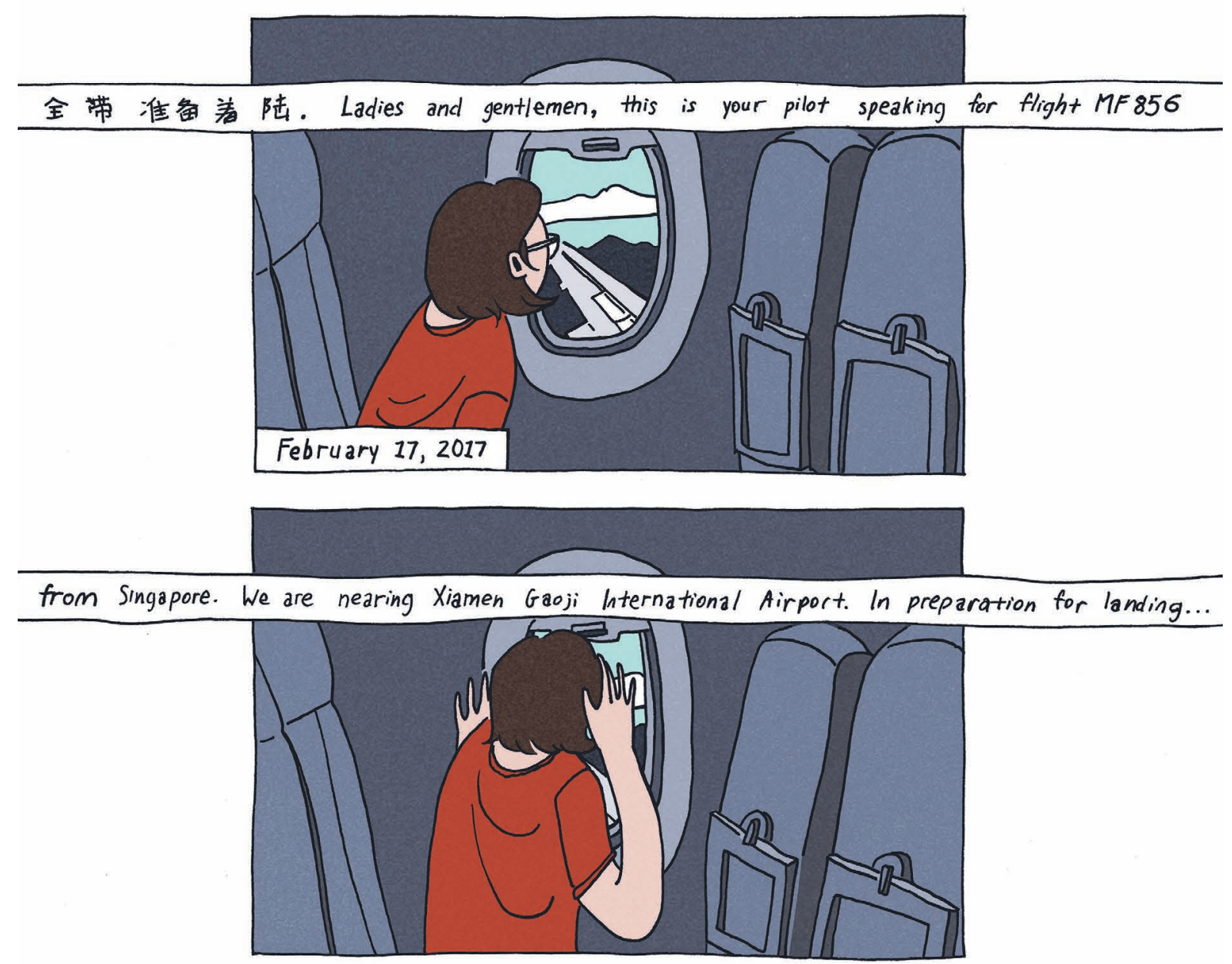

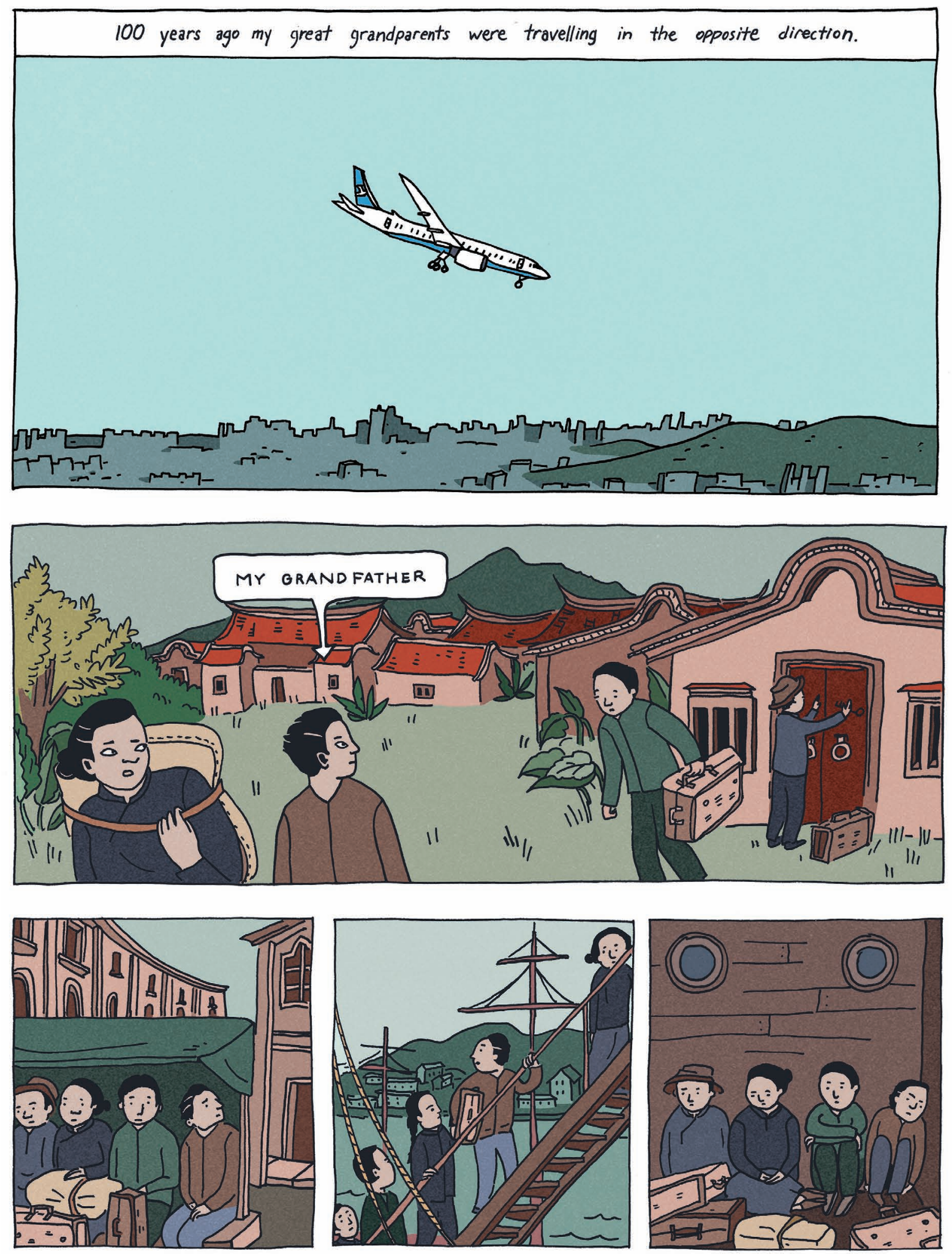

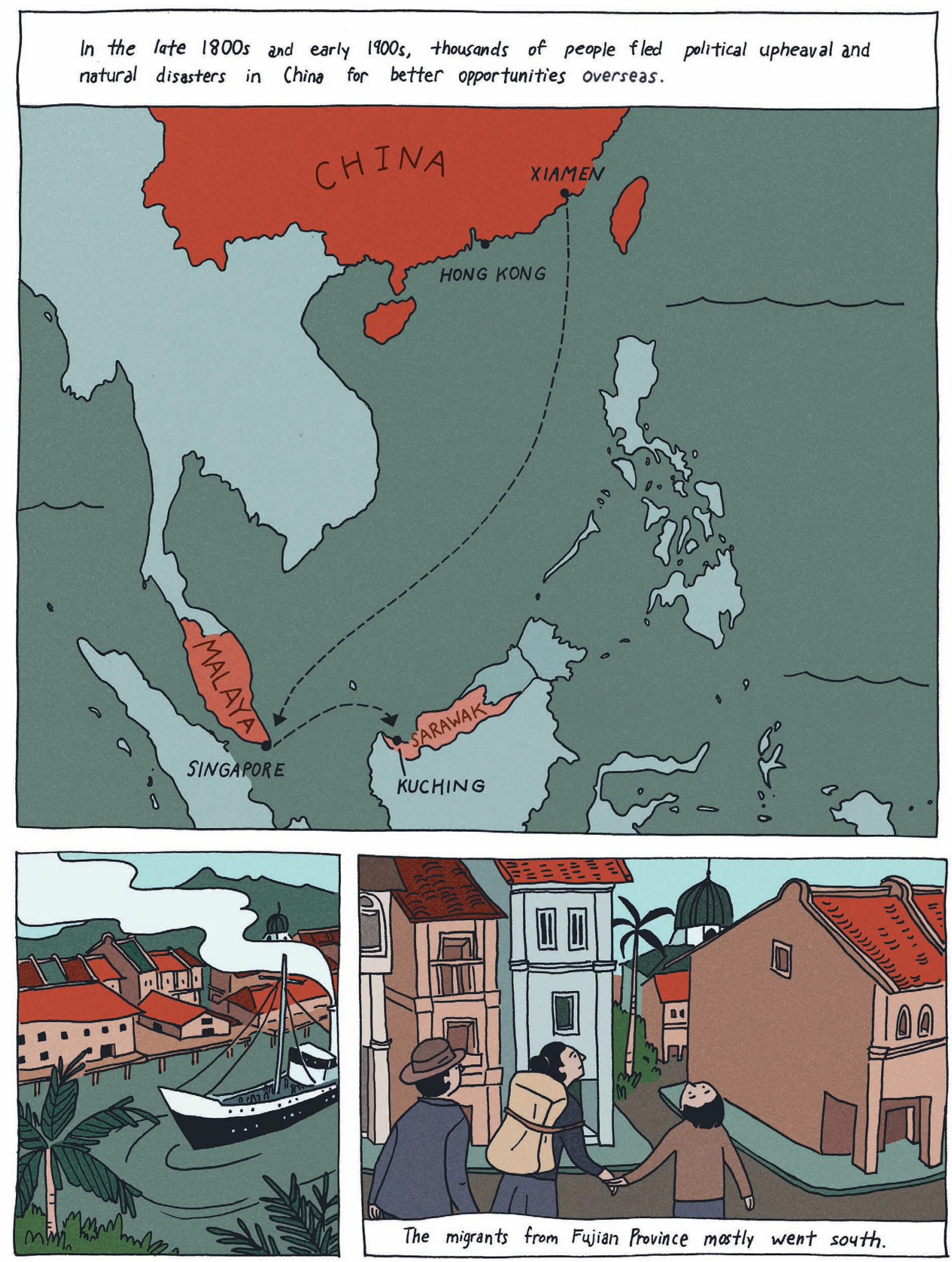

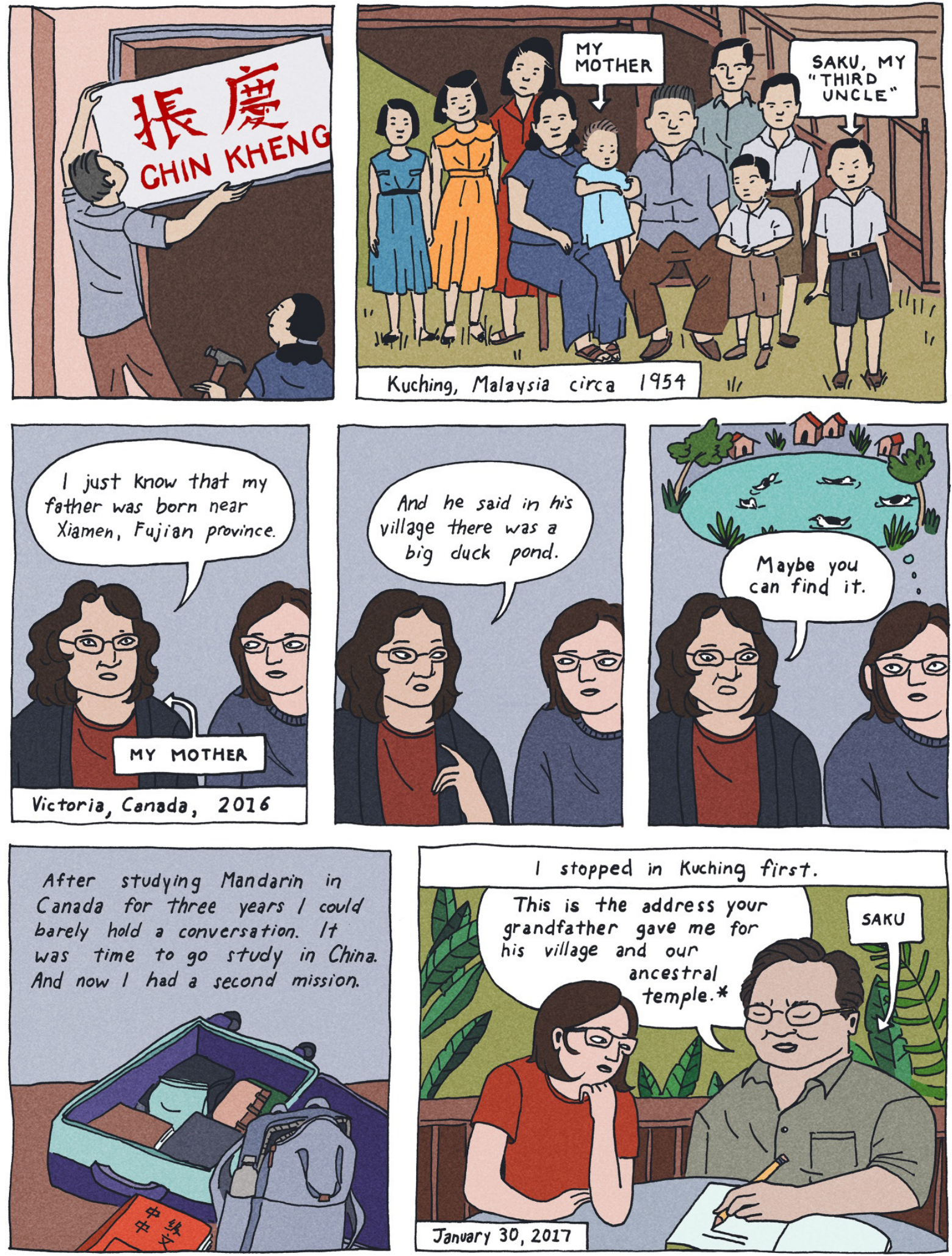

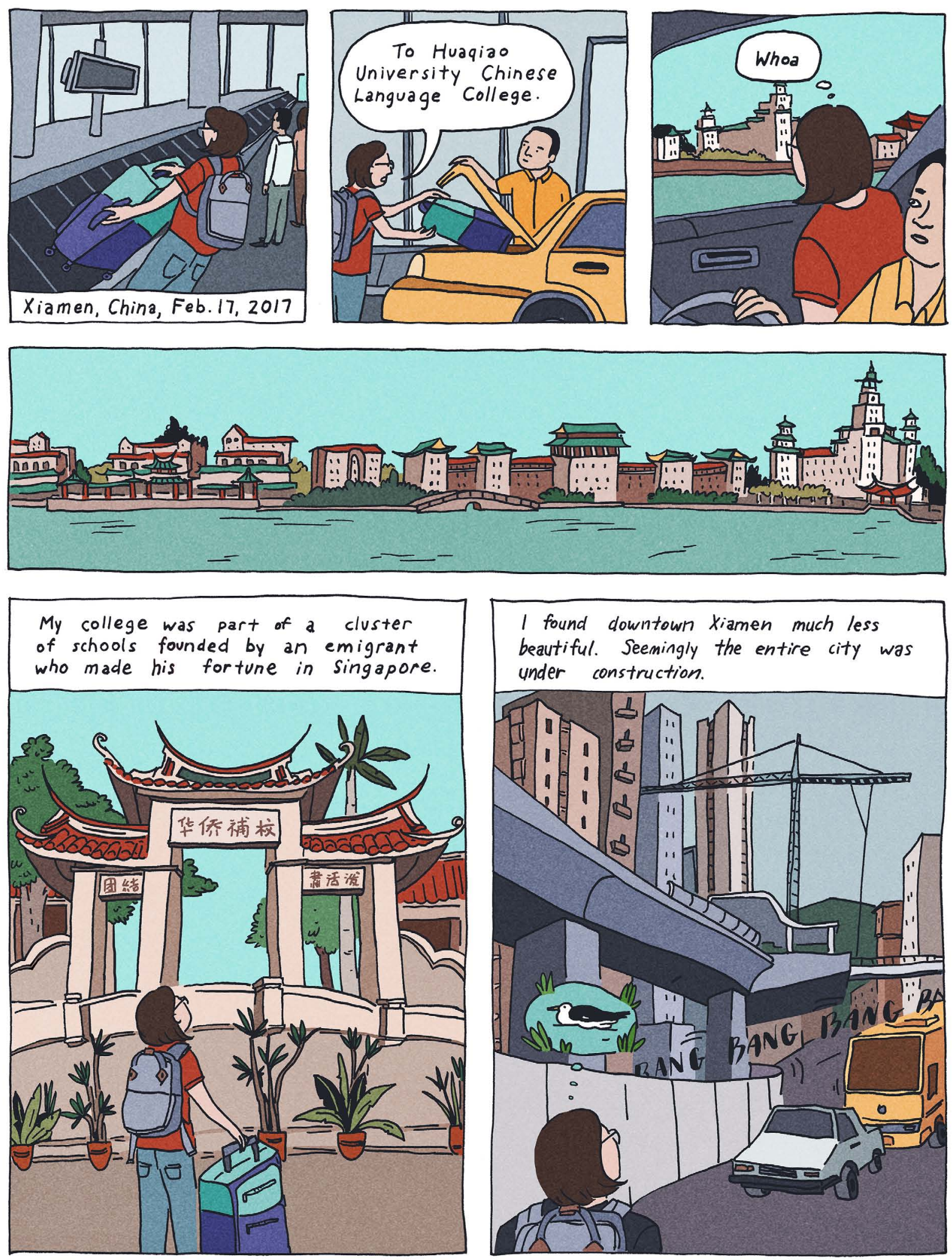

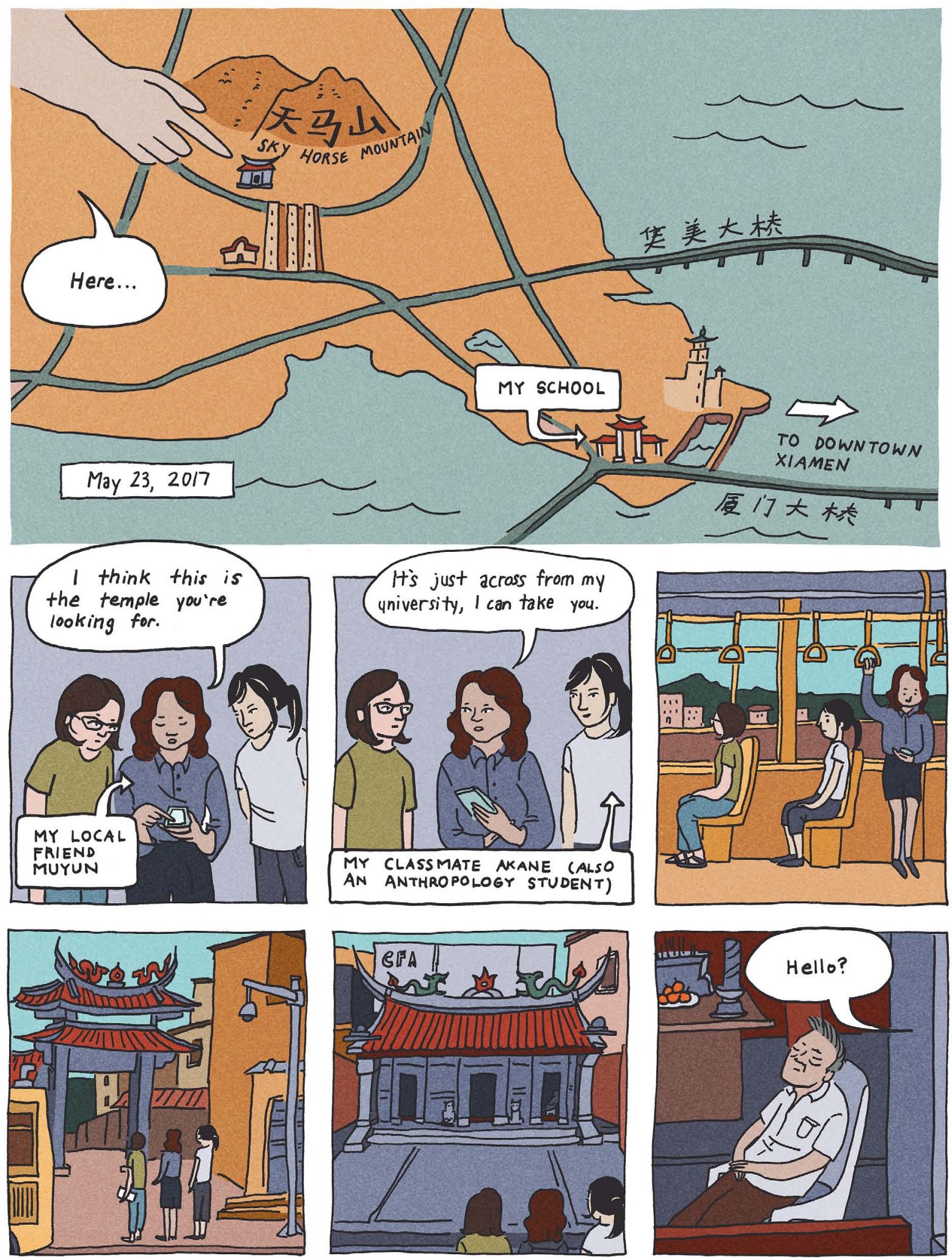

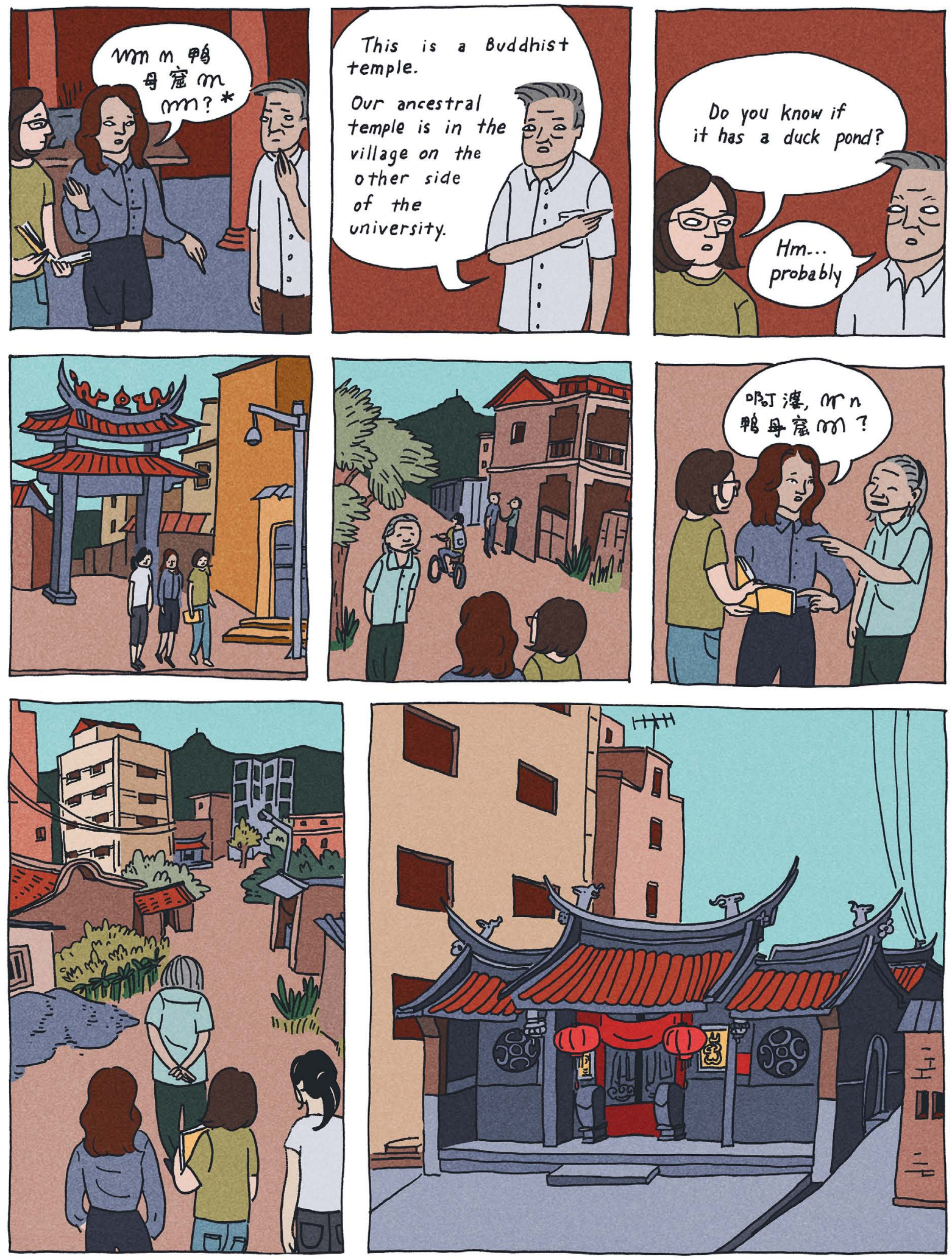

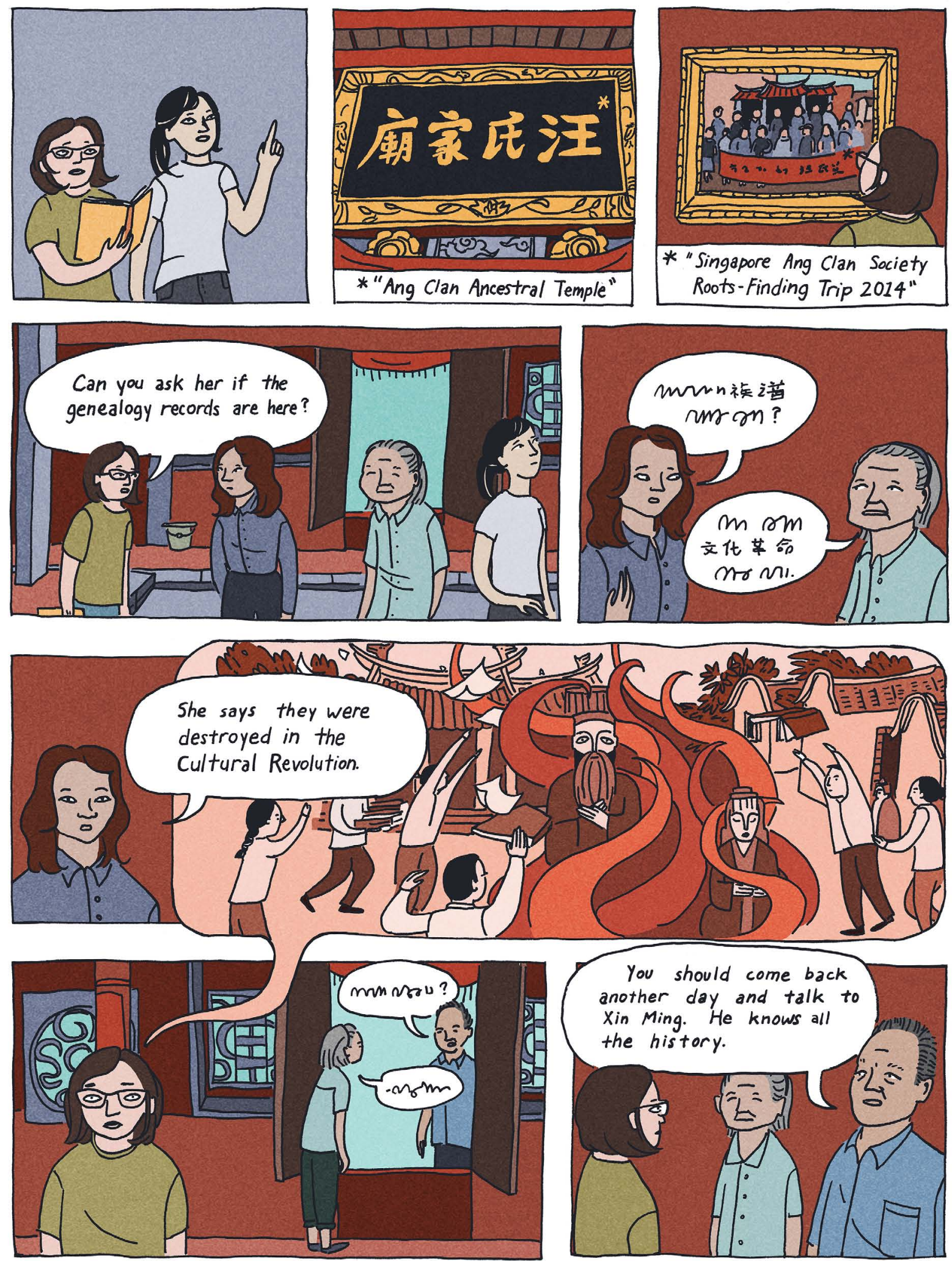

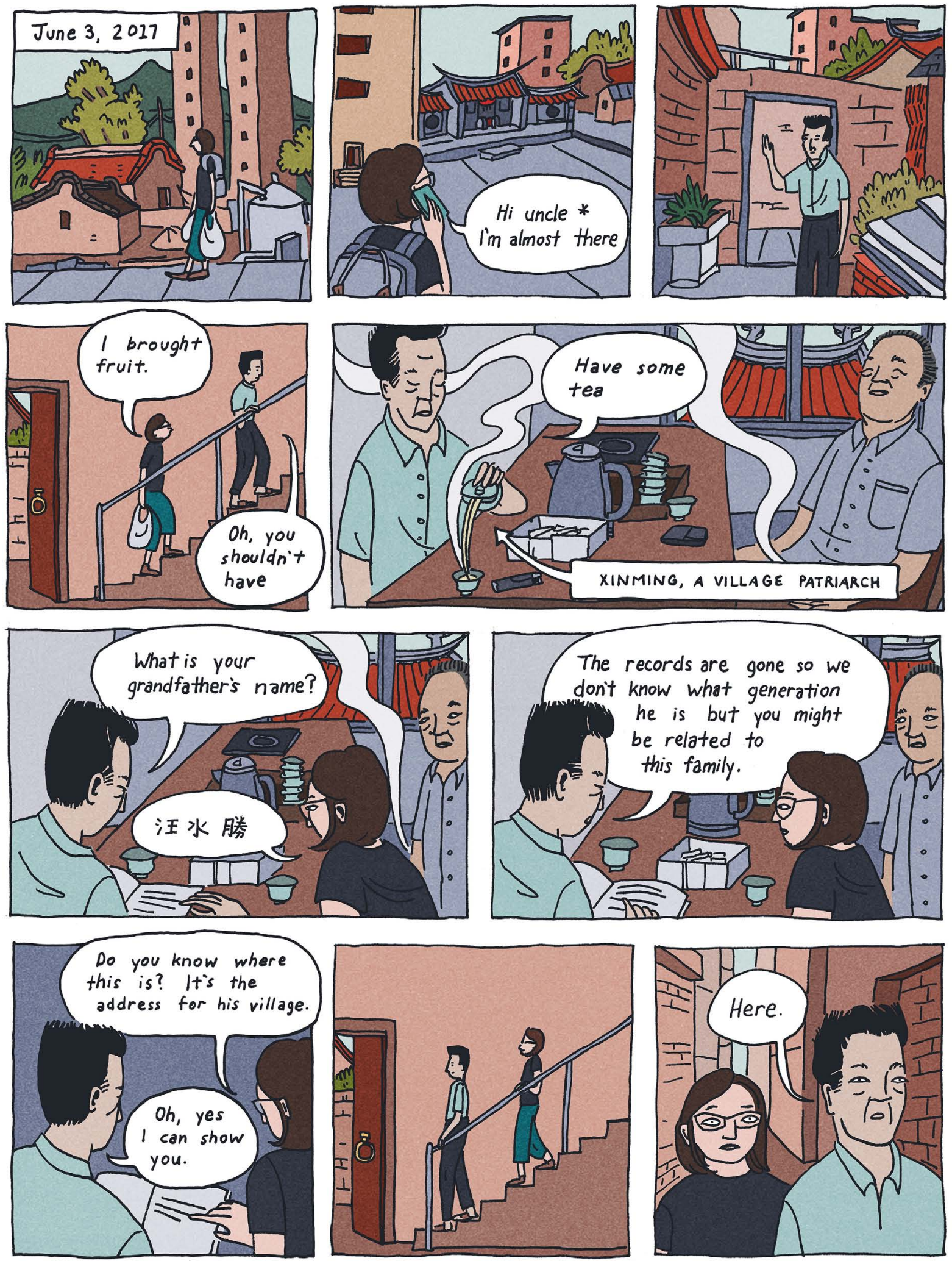

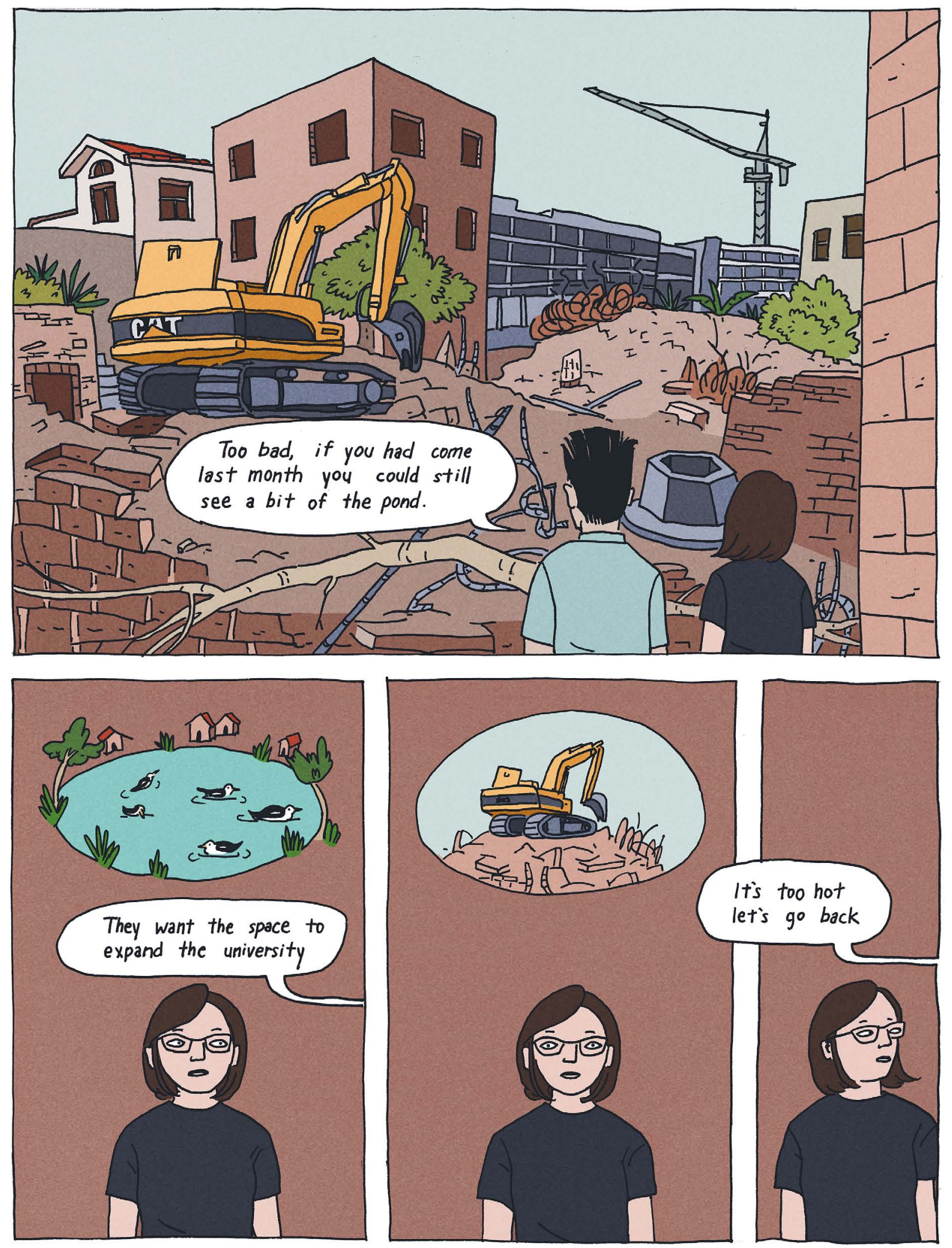

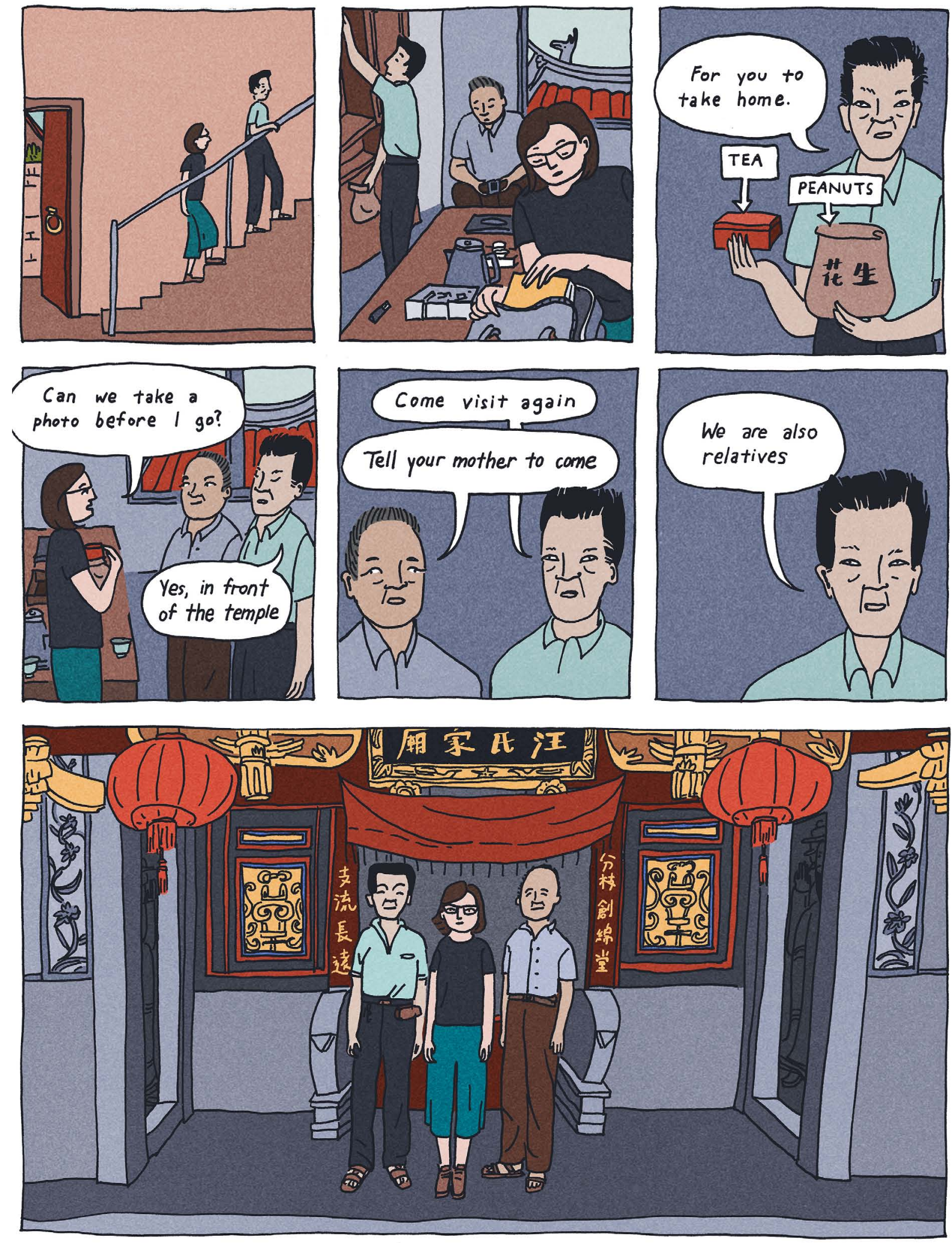

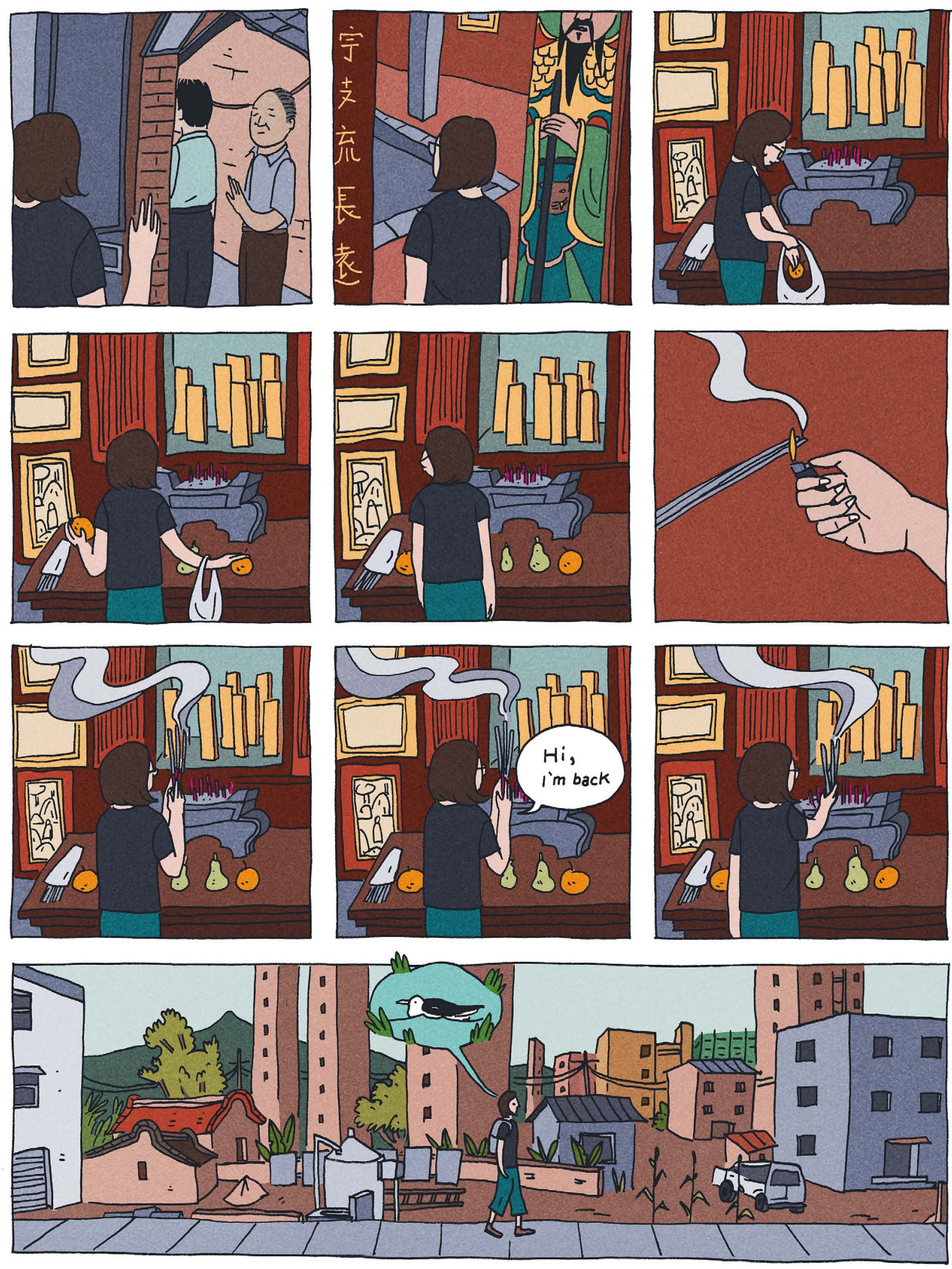
In 2017, I took a break from my anthropology degree to go to Xiamen, China. I had two missions: to improve my Mandarin, and to find the village where my grandfather was born. My grandfather's family moved from China to Kuching, Malaysia when he was seven years old. He remained in Kuching until his death in 1979. In 1992 my parents went on vacation in China and spent two days searching for his home town. All they knew was that the town was somewhere near the coastal city of Xiamen and my grandfather kept mentioning a duck pond. At that time transportation was slow and they couldn't find the right village before they needed to catch their train to Hangzhou. No one else in my family had found the village. In Canada, as well as studying anthropology I was grappling with how to live ethically on land dispossesed from Coast Salish indigenous people, and where my family's roots barely go back thirty years. I realised that to do those things I should start with knowing where I'm from. Also, it was the set-up for a good story.

I spent my time in Xiamen studying at a Chinese language college, and recording images, events, and things-learned in a series of sketchbooks that were part journal and part field notebook. Drawing everyday life was my attempt to notice all the details of the place where my ancestors lived a hundred years ago. In Drawn to See, Andrew Causey argues that humans neglect most of the visual world around us, processing only the information that is necessary to function at a given moment (2016:13-14). Drawing can help an ethnographer, or anyone, to pay closer attention by mirroring the physical form of the thing drawn with the movement of a pencil or pen. The marks left behind are evidence of what one has truly seen (Causey 2016; Ingold 2011; Taussig 2011).
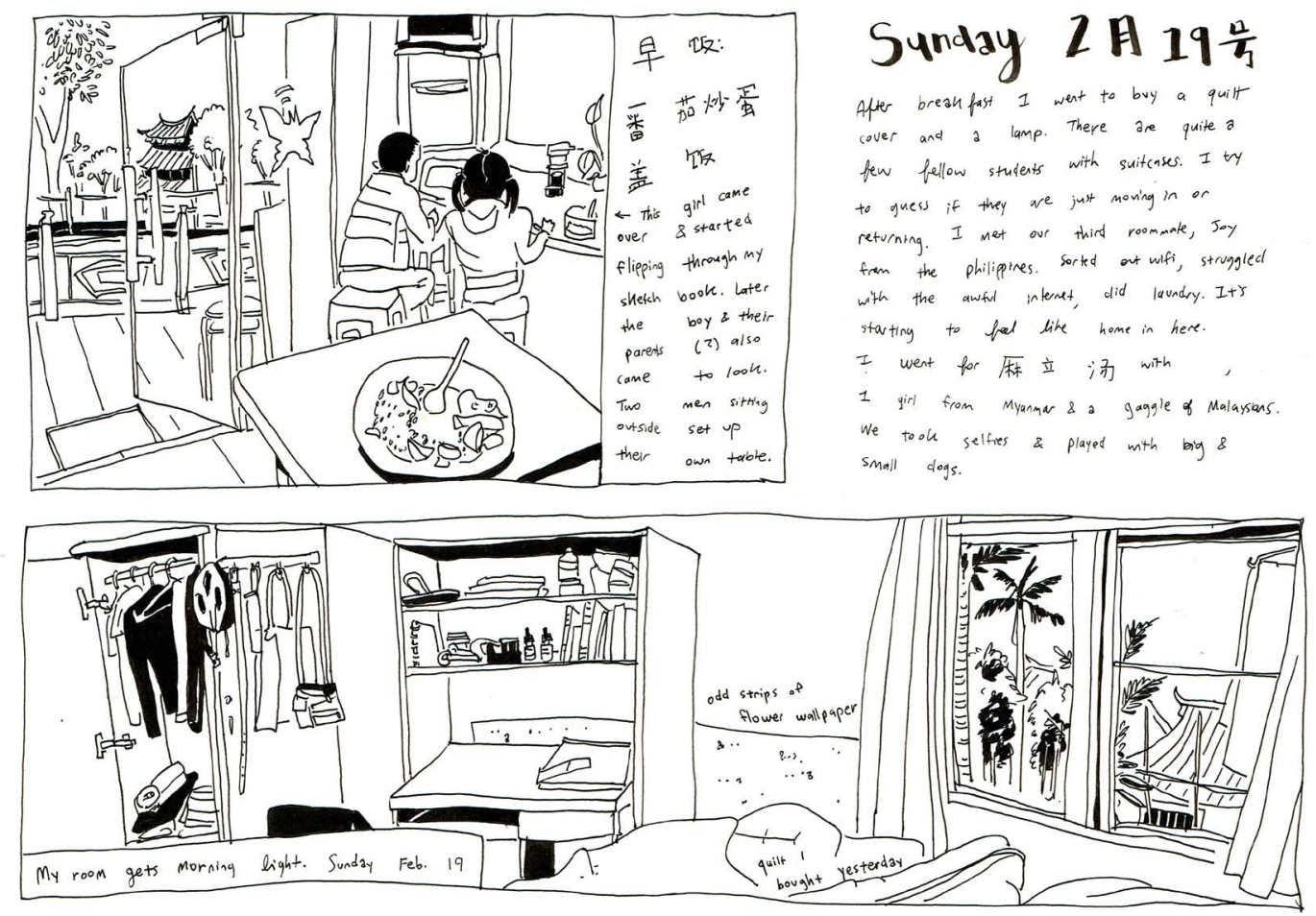

Figure 1. Drawing from my first week in Xiamen.

I waited to look for my grandfather's village for a few months after I arrived in Xiamen. Eventually, I found it only a half hour bus ride away from my college. Like other villages around 
Xiamen, it is still a distinct settlement but over time it has been engulfed by the city, surrounded on all sides by highways and universities. My first two trips there are recounted in the "The Duck Pond" comic.

After I found the village, I returned every couple of weeks. These visits were mostly spent in Uncle Xinming's study drinking endless cups of tea. ${ }^{1}$ Xinming has a vibrant social life and other visitors were always dropping in and out. I tried to ask questions but often these visitors were content to chat with each other in Hokkien instead of talking to me in Mandarin. At times like these sketching allowed me to blend into the scenery and soak in the details of the room.

Like Manuel João Ramos, I found there is something about drawing that invites curiosity, whereas photography tends to create a barrier between a photographer and the environment (Alfonso and Ramos 2004). Sketching also allowed me to be unobtrusive at times when photography would not have.

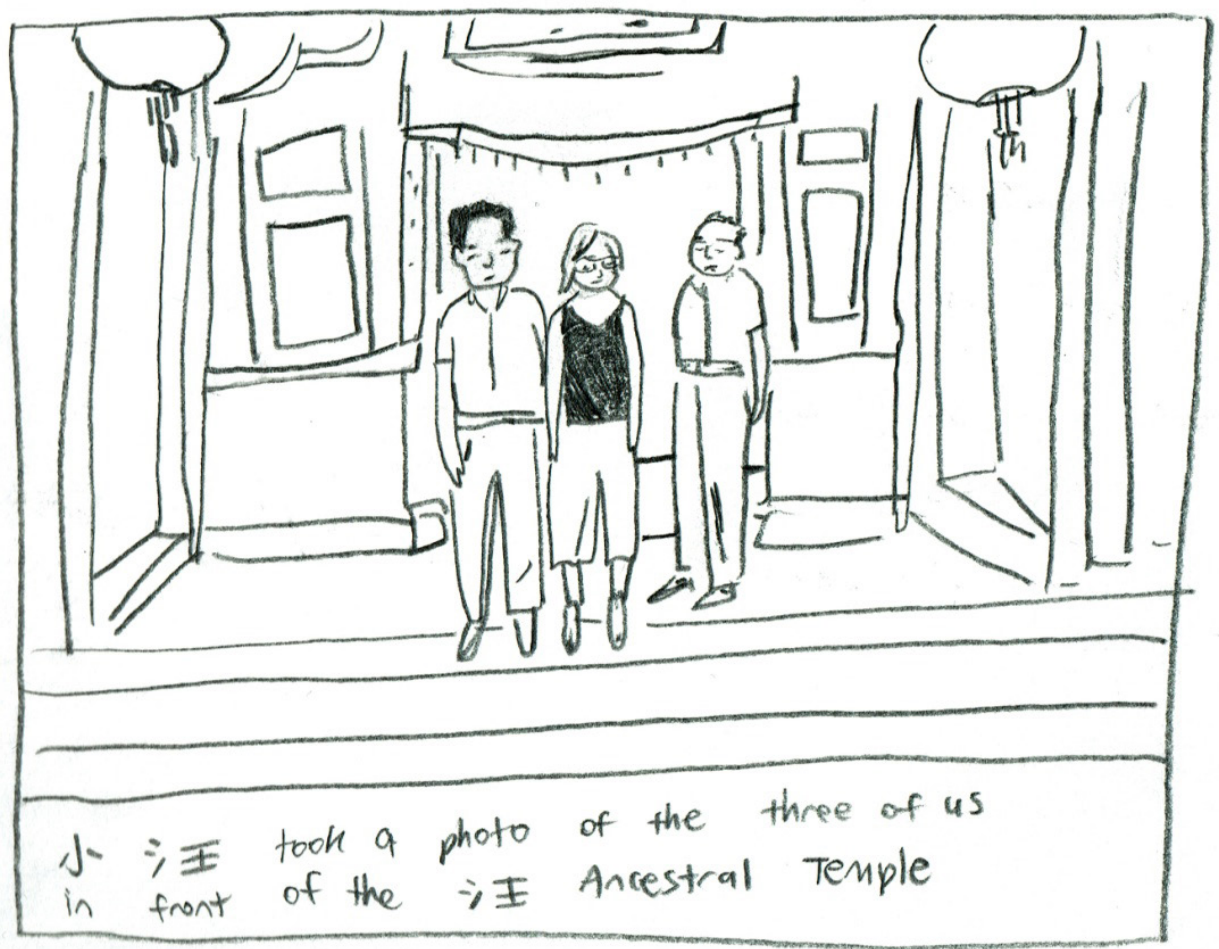

Figure 2. A sketch in my notebook after my second trip to the village.

1 In Xiamen, 叔叔 shushu (uncle) refers to men around your parents' age or older regardless of whether you are related. Xinming is also actually my very distant uncle. 


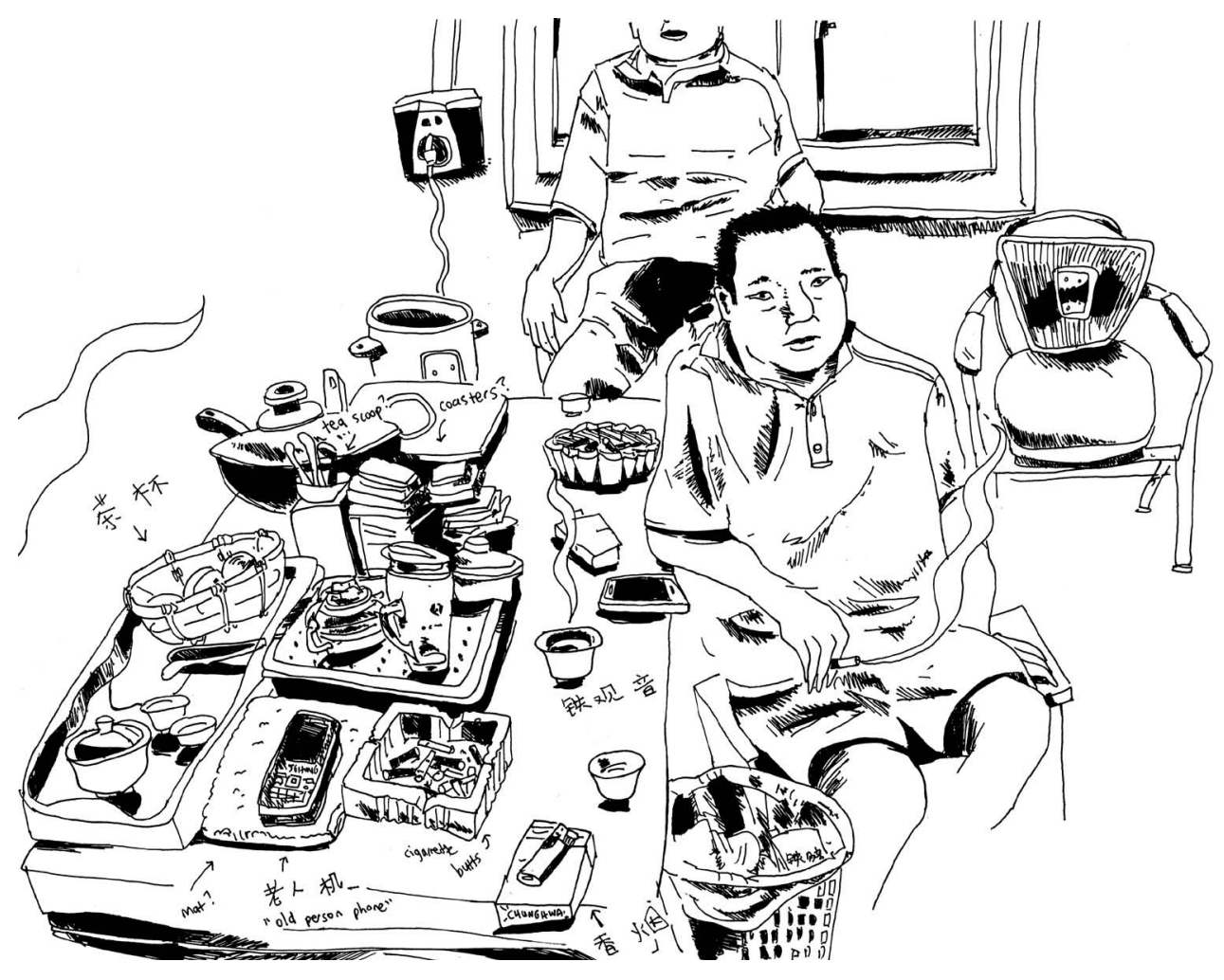

Figure 3. The drawing of Uncle Xinming's living room that is the main reference image for page 8 of the comic.

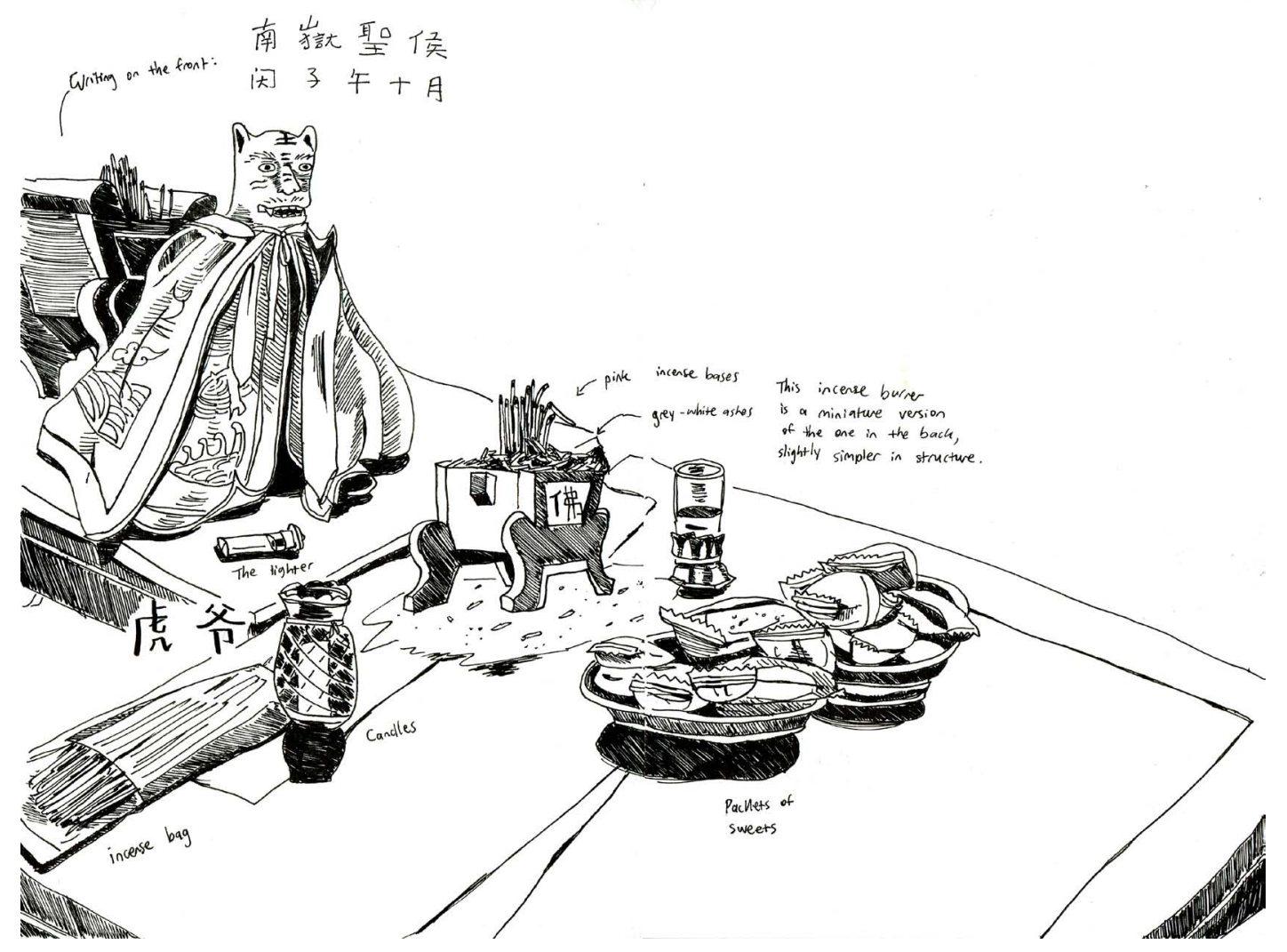

Figure 4. An altar at the ancestral temple. 
When I wasn't in Xinming's study I was often trying to draw the ancestral temple: the one part of the village that in a way belongs to me. More than anything else, drawing temples in China taught me about the difficulty of processing the visual world. Every temple I tried to draw would inevitably defeat me when I lost track of my lines in the tangle of ceramic fish and chrysanthemums. But if I had not tried to draw them, I would not have understood how much Minnan architecture is dense with form and meaning. ${ }^{2}$ Later I learned to focus on one small part of a building at a time. For example, Figure 4 is a documentation of the objects on an altar in the ancestral temple that all serve a specific purpose.

Toward the end of my months in China I became more interested in how to capture the feeling of experiences and places, rather than just their physical existence. Like Causey asks, "Is there any way to depict the surface but also represent the vibrant entity that pulses beneath?" (2017: 111)

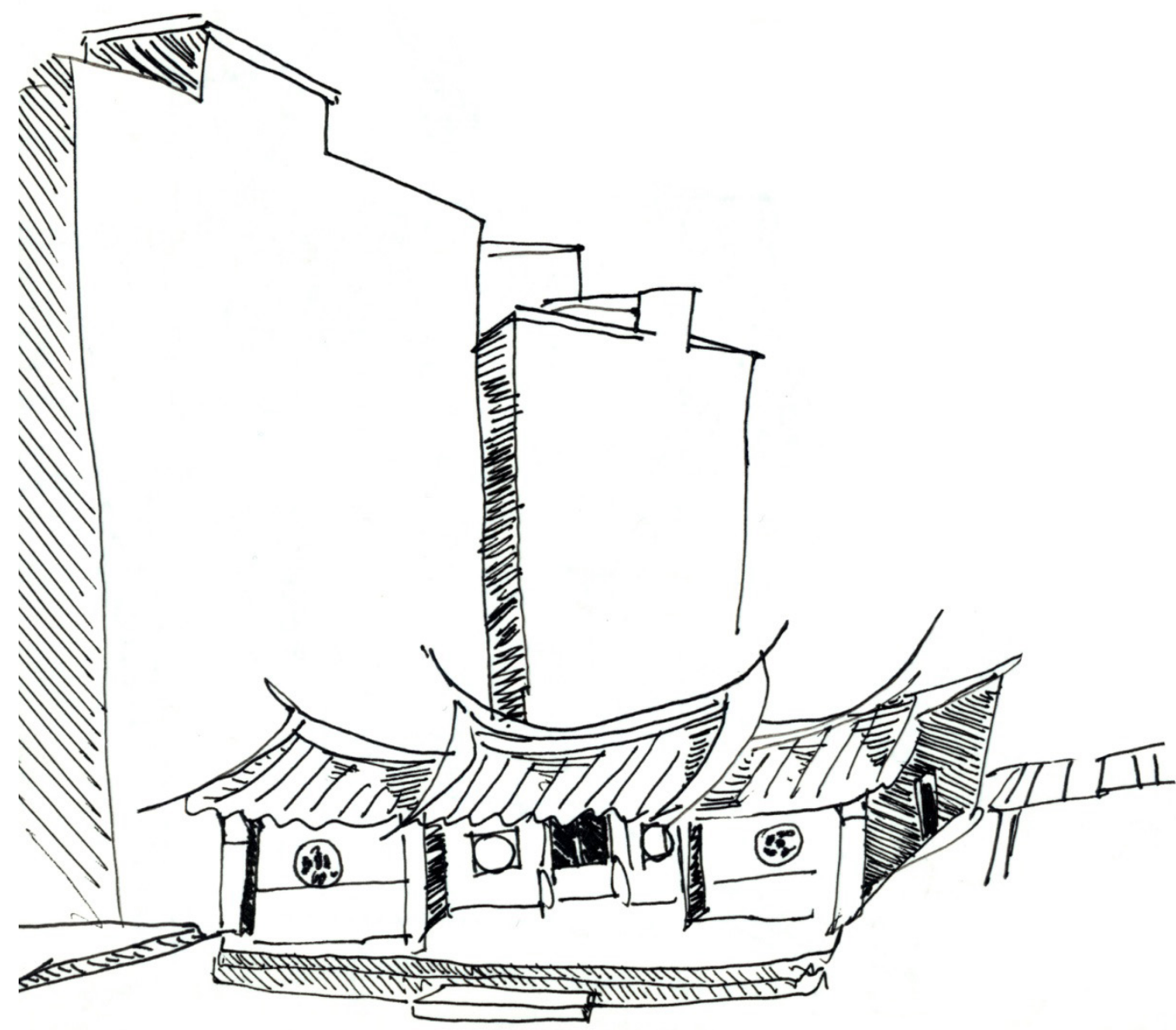

no lions at the door.

Figure 5. A sketch of the ancestral temple that is a reference for page 5 of the comic.

2 闽南 Minnan people make up a linguistic and cultural group that originates in southeastern Fujian Province and eastern Guangdong Province. "Minnan" is sometimes used interchangeably with "Hokkien." 
My strongest impression of Xiamen was the juxtaposition of centuries of cultural continuity with the extremely rapid change of the past decade. I drew the sketch in Figure 5 to capture the feeling of the ancestral temple which has been built and re-built in the same spot for centuries sandwiched against buildings constructed just a few years ago.

Michael Taussig says, "in pointing away from the real, [drawings] capture something invisible and auratic that makes the thing depicted worth depicting" (2011: 12). I found that this is a good way to describe drawings made from memory alone. They are good for capturing the essence of an experience.

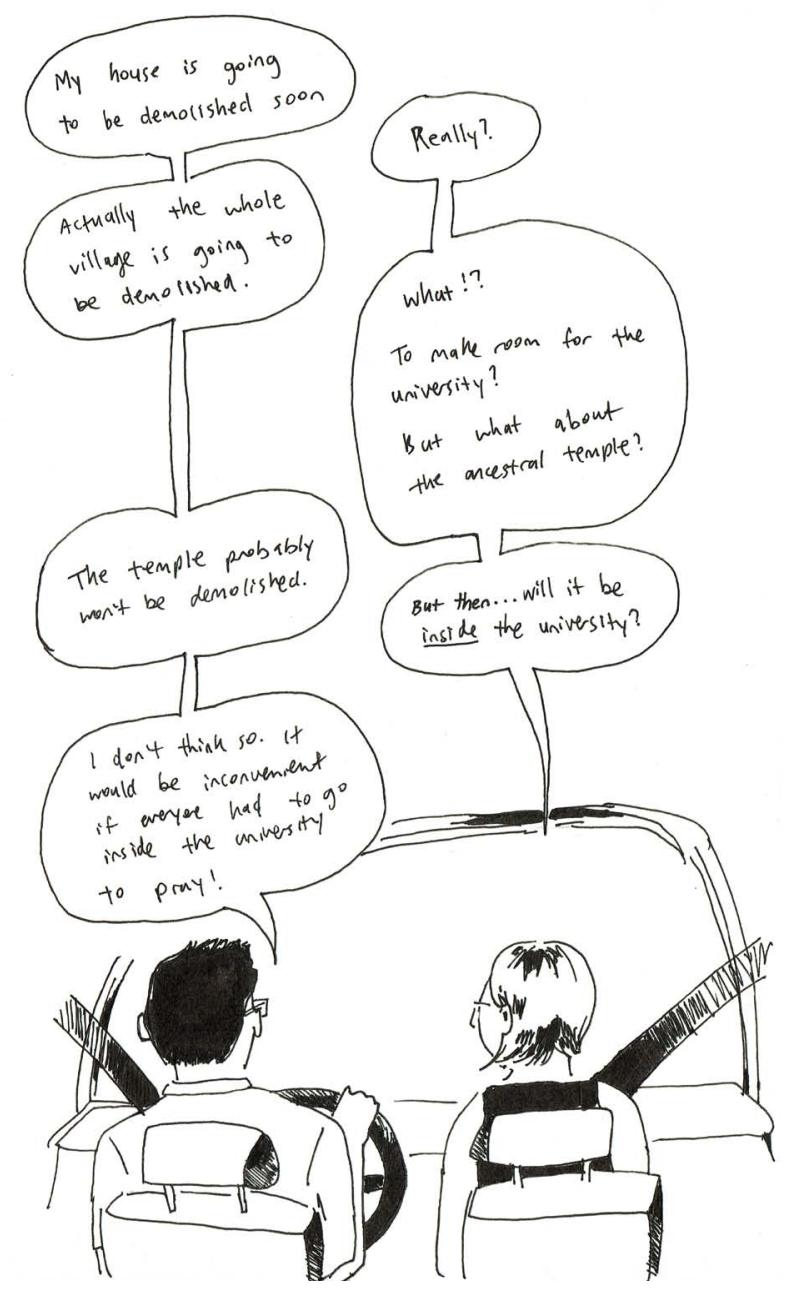

Figure 6. A drawing of a remembered conversation.

When I left for China I knew I wanted to make a comic out of my sketches, notes, and photos. Non-fiction comics are a growing genre and excitingly, some social scientists are investigating using the comics medium to conduct and communicate research (Kuttner, Sousanis, and Weaver-Hightower 2017). ${ }^{3}$ The seamless integration of words and images can communicate an idea with a density and clarity that neither can achieve alone. Comics ethnography may

3 Non-fiction comics began to take off with the publication of Maus (1991) by Art Spiegelman and Persepolis (2003) by Marjane Satrapi. The comics journalism genre was pioneered in the 1990s by the work of Joe Sacco (1993) and continues to grow. For a round-up of the latest comics journalism see The CoJo List newsletter: http:// www.tinyletter.com/cojo. 
not be its own genre yet but I think its potential has already been proven by observant cartoonists of everyday life. For example, the Malaysian cartoonist Lat (1979) illustrates episodes of daily life in the 1950s and 60s that are the thickest of "thick description" (Geertz 1970).

When I got back to Canada I re-read all of my sketchbooks. I started creating "The Duck Pond" with a very rough storyboard, and then a slightly tidier storyboard with text and dialogue. Then I assembled a collection of reference images from my own drawings and photographs, historical photographs, and stock images. I pencilled the comic, inked and lettered the line art with a Rotring graphic pen, and corrected and coloured it in Photoshop. I learned useful tips for this process from Drawing Words and Writing Pictures by Jessica Abel and Matt Madden (2008).

During this process I passed drafts of the comic around and got feedback on historical accuracy from my family. While I have tried to be as factual as possible, one strength of drawing is that it can imagine in the gaps where there is no photographic record. For example, I do not have any historical photos of my grandfather's village, so the second panel on page two is a guess based on traditional architecture that exists today. I also condensed the sequence of events into a more compact narrative. I rarely turned on a voice recorder during my trip, so all conversations in this story are paraphrased.

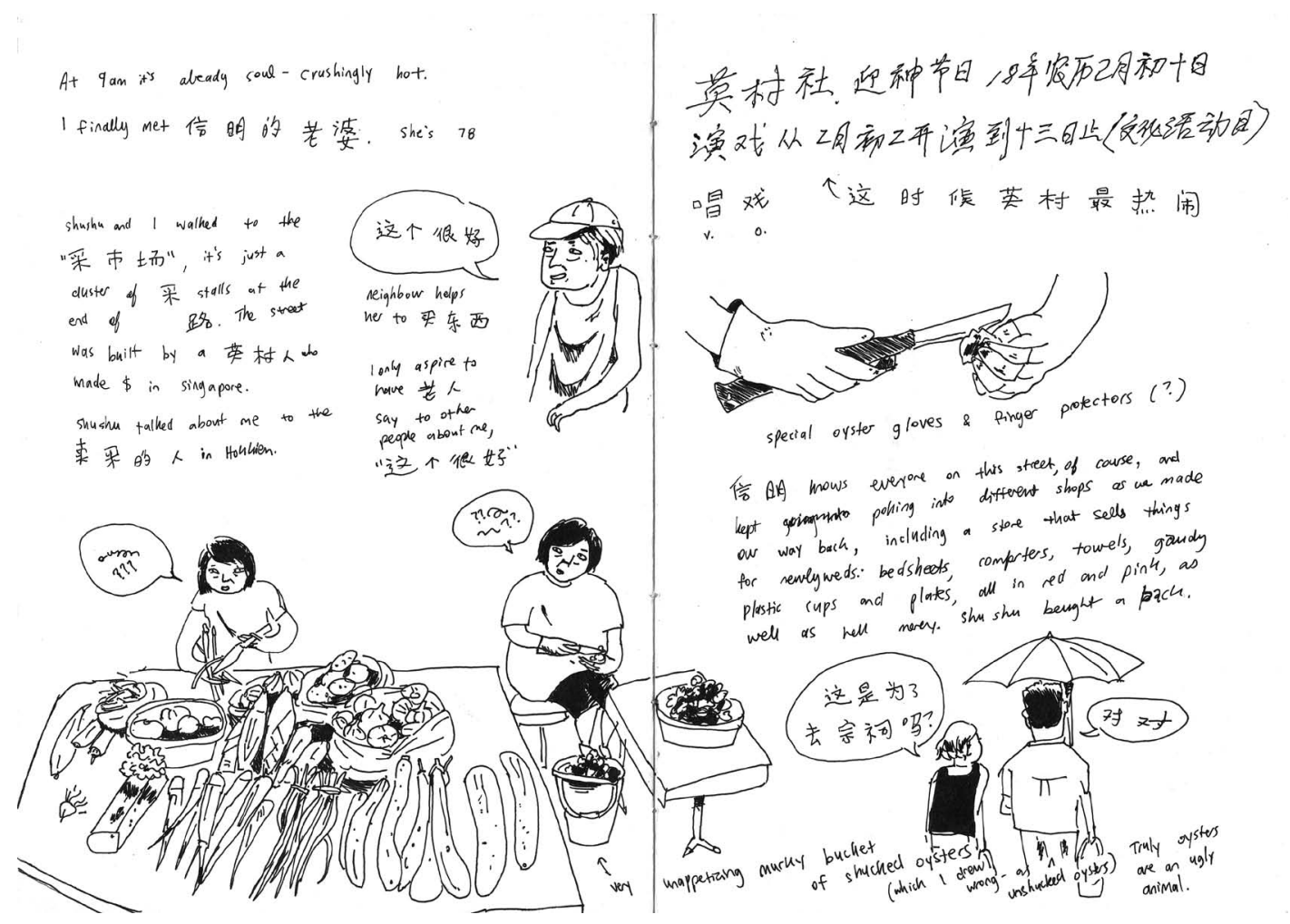

Figure 7. Drawings from memory about a morning in the village.

It's a bit strange living life when you know you are going to make a story about it. I put off searching for the village for several months partly because I was nervous that if it didn't go well I wouldn't have the good story. When I realised I had just missed seeing the last remnants of my coveted duck pond, I was devastated. But back in my dorm room that night I realised that not seeing the pond was also a good story. The narrative changed from a perfect story about 
searching and finding to a story about searching for something that doesn't exist, but finding something else. The process of creating a comic forced me to distill the most important understandings out of my experiences, and like writing a text or editing a film it helped to make meaning out of messy reality.

\section{REFERENCES}

Abel, Jessica and Matt Madden. 2008. Drawing Words and Writing Pictures: Making Comics, Manga, Graphic Novels, and Beyond. New York: First Second.

Alfonso, Ana Isabel and Manuel João Ramos. 2004. "New graphics for old stories: Representation of Local Memories through Drawings." Pp. 72-89 in Working images: Visual research and representation in ethnography, edited by S. Pink, L. Kürti, and A. I. Afonso. New York: Routledge.

Causey, Andrew. 2016. Drawn to See: Drawing as an Ethnographic Method. Toronto, Canada: University of Toronto Press.

Geertz, Clifford. 1970. "Thick description: Toward an interpretive theory of culture." Pp. 3-30 in The interpretation of cultures: Selected essays, edited by C. Geertz. New York: Basic Books.

Ingold, Tim. 2013. Making: Anthropology, Archaeology, Art and Architecture. London, England: Routledge.

Lat. 1979. Kampung Boy. New York: First Second.

Taussig, Michael. 2011. I Swear I Saw This. Chicago: The University of Chicago Press.

Date received: 2019-01-03

Date accepted: 2019-03-15 